\title{
TPMT*3A Allele
}

National Cancer Institute

\section{Source}

National Cancer Institute. TPMT*3A Allele. NCI Thesaurus. Code C45689.

Human TPMT*3A allele is located in the vicinity of $6 \mathrm{p} 22.3$ and is approximately $26 \mathrm{~kb}$ in length. This allele, a variant form of the TPMT wild-type allele, encodes thiopurine Smethyltransferase protein. TPMT*3A allele exhibits two clinically-relevant SNPS (c.615G $>C$ and c.874A $>G$ ) in that results in coding changes (A154T and $Y 240 C$ ). Together, these alterations abolish the enzymatic activity of the protein encoded by this allelic variant. 